Article

\title{
The Challenge of Folklore to Medieval Studies
}

\author{
John Lindow
}

Department of Scandinavian, University of California, Berkeley, CA 94720-2690, USA; lindow@berkeley.edu

Received: 21 November 2017; Accepted: 30 January 2018; Published: 7 February 2018

\begin{abstract}
When folklore began to emerge as a valid expression of a people during the early stages of national romanticism, it did so alongside texts and artifacts from the Middle Ages. The fields of folklore and medieval studies were hardly to be distinguished at that time, and it was only as folklore began to develop its own methodology (actually analogous to medieval textual studies) during the nineteenth century that the fields were distinguished. During the 1970s, however, folklore adopted a wholly new paradigm (the "performance turn"), regarding folklore as process rather than static artifact. It is here that folklore offers a challenge for medieval studies, namely to understand better the oral background to all medieval materials and the cultural competence that underlay their uses.
\end{abstract}

Keywords: history of scholarship; folklore methodology; medieval studies; performance; orality; cultural competence

Writing about Herder's pleas to his fellow countrymen to collect folklore and thus to document the unique nature and history of the nation that then existed only theoretically and philosophically, William A. Wilson wrote:

Two of the first to respond to Herder's call were Friedrich David Gräter and Christian Gottfried Böckh who, inspired by Herder's writings, founded a periodical called Bragur, ein literarisches Magazin fur deutsche und nordische Vergangenheit, which was dedicated to the collection and publication of folklore. In the ensuing years others joined the cause. In 1803 Ludwig Tieck published Minnelieder aus dem Schwäbischen Zeitalter. From 1805 to 1808 Clemens Brentano and Achim von Arnim published three volumes of folksongs entitled Des Knaben Wunderhorn: alte deutsche Lieder. In 1807 Josef Görres published the results of his studies of almanacs and old storybooks. In 1812 Jacob and Wilhelm Grimm edited ancient fragments of the Hildebrandslied and the Weissenbrunner Gebet and then from 1812 to 1815 published their famous collection of folktales, Kinder- und Hausmärchen. In 1815 they brought out a volume of the Poetic Eddas and from 1816 to 1818 published Deutsche Sagen, an analysis of the oldest Germanic epic tradition. (Wilson 1973, pp. 828-29)

The title of Gräter and Böckh's journal, "Bragur, a literary magazine for German and Nordic antiquity" may seem surprising for a journal that would publish the verse that according to Herder best represented the spirit of the nascent German nation. Bragur (usually bragr) means "poetry," but it comes from the poetic vocabulary of Old Norse-Icelandic, not German, and another title for the first five numbers of the journal, Braga und Hermode, oder Neues magazin für die vaterländischen Alterthümer der Sprache, Kunst und Sitten (Braga and Hermode, or new magazine for the antiquities of language, art, and customs of the fatherland) strikes modern readers as equally hybridic, since Bragi and Hermóðr are the lead characters in a major myth known only from Old Norse-Icelandic written tradition. The view expressed by these titles relies on the linguistic relationships that had recently been uncovered among

1 Böckh dropped out of the project after the first volume had appeared. 
the Germanic languages: because German and Scandinavian were related, and because the genius of the nation(s) was situated in the past, the monuments of Old Norse-Icelandic tradition were valid representations of the German national spirit. Since those monuments were recorded in the Middle Ages, there was an implicit if not explicit attachment between folklore and medieval studies. The early portion of the career of the Grimms shows this connection clearly. In the same year that the Kinder-und Hausmärchen (Grimm and Grimm 1812-1815) began to appear, they published an edition, with commentary, of two famous poems from Old High German, the Hildebrandslied and the Wessobrunner Gebet (as it is now usually known) (Grimm and Grimm 1812). This edition will look familiar to any medievalist today. The text is accompanied by notes on such matters as language, prosody, the manuscripts, and the thematics of the two poems. Thus while the brothers were preparing the first of the two volumes of folktales that would ensure their fame, they were also producing an early example of the editorial practices of medieval studies. While in the process of bringing out their edition of legends (Grimm and Grimm 1816-1818), a highly influential work in the history of European folklore, they produced an edition and translation of the thirteenth-century Icelandic Poetic Edda (Grimm and Grimm 1815b), another medievalist project, and in that same year they published another edition of a work from the German Middle Ages (Grimm and Grimm 1815a), this time from Middle High German.

Given the then prevailing view of folklore as coming from the distant past, as a national antiquity, this overlap is hardly surprising. It was in fact the norm throughout the nineteenth century. ${ }^{2}$ Thus the first academic appointment at the University of Copenhagen in the field of folklore occurred when Svend Grundtvig, the great ballad scholar, was appointed "extraordinary lecturer" in Nordic philology, in part on the basis of his trial lectures on heroic poetry, a medieval topic. In his first lecture upon appointment in 1863, he defined Nordic philology.

It is the branch of scholarship dealing with the spiritual life of the Nordic peoples in all ages and in all its manifestations, the way the spirit of this people has revealed itself and still reveals itself both in the language itself-the words, logos, the immediate expression of the spirit-and in the people's belief and poetry, in its customs, in its whole life. (Piø 1971, p. 222)

This is surely a definition-echoing Herder-of folklore as nineteenth-century scholars regarded it. Interestingly, Grundtvig apparently distinguished between Nordic philology, the academic field, and folkeminder (popular traditions), the term he used in his popular writings. Only later would this term become standard in Danish academic discourse.

A few words on the major scholarly achievement of Grundtvig are worthwhile here (more will be offered below). Danmarks gamle folkeviser is an edition of the ballads of Denmark that still stands as a model for such works. Grundtvig edited written texts from the early Modern period as well as records taken down from oral tradition, which were scarce when he began his project in the 1850s. Given the prevailing view that the ballads were medieval, and the fact that Grundtvig worked with written texts from the early modern period onward as well as recordings from oral tradition, Grundvig and his contemporaries probably considered the project as essentially rooted in Danish medieval literature. ${ }^{3}$

Although the Nordic academic world continued to produce scholars who spanned the growing gap between folklore and medieval studies, or who worked effectively in both fields, a divide began to appear as the field matured during the early years of the twentieth century. A method emerged, based primarily on comparison of archival items aimed at ascertaining the details of content ("motifs" or "traits") in an original form ("archetype") of a given item of folklore and the development of the item

2 The remainder of this paragraph relies on (Piø 1971).

3 Grundtvig's title means "Old Danish popular ballads." The much later Swedish and Norwegian editions are called respectively Sveriges medeltida ballader (Sweden's medieval ballads) and Norske mellomalderballadar (Norwegian medieval ballads). The type catalogue is called Types of the Medieval Scandinavian Ballad. 
in time and space. Folklorists believed it constituted a method unique to the field, the "folkloristic method" ("folkloristische Arbeitsmethode") as Kaarle Krohn called it in a series of programmatic lectures in 1924-1925 (Krohn 1926, 1971) and as it was presented in a classic case study, intended to exemplify the method, by Archer Taylor (Taylor 1927). Formulated by Krohn's father, Julius Krohn, in a series of studies of Finnish oral poetry, and carried on by Krohn and others, the method is usually referred to as "historic-geographic" but came too to be known as the "Finnish method," given its heritage; and when applied to Finnish materials, it was indeed focused virtually exclusively on archival materials collected from oral tradition. A scholar working on Kalevala-related poetry was not and could not be regarded as a medievalist for the simple reason that there were no medieval recordings-indeed, virtually no older written recordings - of such poetry. Thus a de facto split with medieval studies necessarily grew out of the formation of "folklore" (i.e., historic-geographic) methodology.

Nevertheless, a self-evident similarity exists between the folkloristic historic-geographic method and the textual criticism that scholars had long used when editing the Bible and perfected during the nineteenth century editing classical and medieval literature. Both methods involve comparison of items in a given structure ("motifs" or "traits" in items of folklore; words and forms in manuscripts). Both aim to unearth or reconstruct the oldest form of the text that is under scrutiny (see below on texts in this early folklore method). The "normal form" of the historic-geographic method clearly recalls the nodes in the stemmata of textual criticism, and both fields developed explicit methods, often called "rules" or "laws," for judging the relative value of the comparanda when postulating older forms, of which the most famous in textual criticism is perhaps privileging the lectio difficilior. Krohn articulated the 'laws' for folklorists on more than one occasion (Krohn 1891, pp. 8-9; 1971, pp. 59-100), and Taylor (1927) showed them in action in the analysis of a single tale.

It is certainly true that other disciplines influenced the emerging discipline of folklore, among them botany and biology (Hafstein 2001). More generally, the historic-geographic method can be understood as one of the strains of diffusionism, which "dominated ethnological thought 1910-1925" (Hultkrantz 1960, p. 94). Nevertheless, it is fair to say that the historic-geographic method is as close to textual criticism as to, say, Kulturkreislehre, because both textual criticism and the historic-geographic method focus on texts. The origins of the historic-geographic method lay in Julius Krohn's research into Kalevala-related poetry. Although this form could be used for charms and laments, Krohn focused on the prehistory of the narrative songs (Finnish runot), and his son Kaarle continued this line of research. He also, however, was a prolific collector of folklore, and some 18,000 items of folklore in the archive are due to his efforts, about half of them folktales (Pentikäinen 1971). As the number of folktales collected by Krohn suggests, folklorists were deeply interested in that form, and many of the early monographs employing the historic-geographic method studied individual tales. ${ }^{4}$ And given the large numbers of tales that had been collected, and language barriers, folklorists using the "historic-geographic" method allowed themselves to work not with the full archival recordings but rather with short abstracts of the tales. This did constitute a departure from the editing principles of medievalists, whose attention was fixed not on "motifs" or "traits" but rather on words, and in some ways approached more closely the methodology of the ethnologically-oriented diffusionists. Nevertheless, in retrospect the debt of early folklore scholarship to textual criticism, especially as practiced by philologists working on the vernacular medieval textual traditions, is obvious. Moreover, the theories that some folklorists advanced applied, in their minds, equally to folklore in the field and to medieval vernacular traditions. An important example is provided by the "epic laws of folk narrative" formulated by Axel Olrik (Olrik 1908, 1909, 1965), which he believed

4 In the early years of the twentieth century, Krohn joined the Dane Axel Olrik and the German Johannes Bolte to found the Folklore Fellows, an organization that aimed to promote access to and publication of folklore materials. FF Communications began publication in 1910, and the overwhelming majority of works published over the next few years consisted first of catalogues of tales and then historic-geographic analyses of tale types, as they were called. 
applied to "all European folklore" (Olrik 1965, p. 131). In providing the examples for his laws, Olrik very frequently used Nordic heroic literature and Nordic and Celtic myth; all are medieval. ${ }^{5}$

If transferred to textual criticism, the historic-geographic method would be analogous to a variorum edition insofar as the scholar was required to consider all the extant versions of a given type. Thus, folklorists took into consideration ancient written materials, including medieval ones. Beyond that, sometimes folklorists took as their research focus the identifying of "folklore" (i.e., common folktales and the like) in literature, quite often medieval literature. So matters remained for the half-century of so following Krohn's lectures in 1924-1925. Although work of this kind still goes on, the process culminated in the Festschrift for Francis Lee Utley (Mandel and Rosenberg 1970), of which virtually all the contributions concern medieval texts. ${ }^{6}$

When the Utley Festschrift appeared in 1970, there was already a discussion among folklorists that would lead to the "performance turn:" the conception of folklore as event or process rather than as item, and consequent refocusing of the kinds of questions folklorists chose to analyze. This fundamental insight-namely that within tradition itself, "items" exist only as part of a process of performance-now animates virtually folklore analysis. How might it be applied to medieval studies?

Early examples of application of this kind of approach looked at medieval records that embodied actual performances. To take but one example, Carl Lindahl (Lindahl 1987) was able to offer subtle and nuanced analysis of the performance situations implicit in Chaucer's The Canterbury Tales. Lindahl's analysis approached the narrators of the frame as real storytellers, each with an identifiable profile, and it showed how there is a social reality behind the fictional characters and their tales. Narrators had individual profiles, to be sure, but there would be no tales without the audience and the situations in which tales were exchanged. Chaucer offers us one such set of situations, but there must have been countless others.

Our understanding of Canterbury Tales is certainly enhanced, but so too is our notion of medieval narrative, for the vast part of it was orally transmitted, and our texts preserve only a tiny bit of what must once have existed. Furthermore, to take the metaphor of performance a bit further, for studying medieval works for the most part we have the scripts, and sometimes through other documents or archaeology an idea of what the theater was like, but we missed the performance. It is easiest to stick to analysis of the script-in this metaphor the manuscript text-but we owe it to ourselves to get an idea of what people did with the script: how actors might have declaimed the lines and what the interaction with the audiences might have been like.

From the point of view of folklore studies, we would naturally ask about the mutual understanding grounded in specific world view and notions of action that created the bond between "performer" and "audience," setting aside our own notions. A worthwhile example of what this entails is to be found in Charles O. Frake's 1964 article on asking for a drink in Subanun (Frake 1964). ${ }^{7}$ The implicit "rules" for this particular performance situation are part of the cultural competence that the participants share and they may be described and analyzed by ethnographers; without them it would be impossible to make sense of the speech acts that take place. From the Middle Ages these speech acts reach us as written texts, and to make sense of them we need to attempt to reconstruct the cultural competence of those who performed and received them. We run the risk of reading them but failing to comprehend them, just as we might remain thirsty after constructing and uttering a grammatically correct sentence in Subanum translating a request for a drink from English. This notion

5 In the 1908 Danish original, although not in the significantly modified German version that made the laws known to the wider world and formed the basis of the English translation (Olrik 1965), Olrik stated explicitly that he intended to take his material from Greek, Nordic, and Celtic myth, from heroic legend (also medieval), and from fairy tales, ballads, and legends, and added that it made no difference where he got his materials; the "laws" would be identical (Olrik 1908, pp. 69-70). In other words, classical and medieval myth and heroic legend were folklore.

6 The exceptions are (Taylor 1970), which treats more or less contemporary anecdotes, and (Thompson 1970), which discusses the documentation of folktales from the perspective of the historic-geographic method.

7 I am grateful to Stephen A. Mitchell for suggesting the relevance of Frake's article in this context. 
applies perhaps most obviously to performative speech acts, such as charms and magic, since for most of us they do not accord with our notion of how the world works; they are not part of our cultural competence. This attempt to get at a very different cultural competence informs work in medieval and early modern magic (e.g., Jolly 1996; Kapaló 2013; Mitchell 2011) but it should certainly be applied elsewhere.

For example, it is common, and normal within our cultural competence, to distinguish myth from heroic legend in the European medieval vernaculars. Thus Scandinavian is singled out as unusual within the extant textual traditions in the Germanic languages for retaining both forms, as against Old English, Old High German, and Old Saxon, which have verse about heroic legend but no myth. ${ }^{8}$ The number of texts is very restricted, and perhaps that should be a warning sign, but the main Old Norse manuscript of poems of both sorts, from the thirteenth century in Iceland, does group poems about gods before (for the most part) turning to poems about human heroes. ${ }^{9}$ A paleographic break between the two parts suggests a similar distinction. But the idea of a strong and clear break between the deity and humans is an artefact of certain religions only, not least Christianity, and before the conversion to Christianity in the tenth and eleventh centuries in Scandinavia, very different notions almost certainly obtained. To take but one example: from the thirteenth-century Icelandic mythographer Snorri Sturluson onward, it was common to distinguish a god of poetry, Bragi, from the earliest known human poet, Bragi Boddason, who we believe lived in ninth-century Norway and who left behind an appealing if challenging body of work. With his Christian worldview, Snorri apparently made nothing of the apparent coincidence of an insignificant god of poetry in the mythology and a robust composer and performer of poetry on earth, and neither did most of the scholars of the nineteenth and twentieth centuries. But upon closer analysis it is clear that in the world view/cultural competence of people in pre-Christian Scandinavia, the distinction between gods and humans was much less sharply drawn than it would be after the conversion. The god Bragi is clearly the human Bragi now living amongst the gods (Lindow 2006). There are many other humans who are closer to the gods than most (Lindow and Schjødt, Forthcoming). This is in fact what we should expect. As Robert Bellah wrote: "In archaic societies, complex chiefdoms, and the tribal societies ... gods, powerful beings, ancestors, and humans exist on a continuum - there are no absolute breaks between these categories" (Bellah 2011, p. 202).

Thus we would expect gradations among beings in the cultural competence of pre-Christian Europe. And yet the inclusion of a non-Christian Other world in cultural competence not only survived the conversion to Christianity; it flourished: dwarfs and elves, fairies and trolls were a part of the landscape. As early as the 1960s the folklorist and historian of religion Lauri Honko produced a model suggesting how narratives about empirical encounters between such beings and humans, termed "memorates" by folklorists (Von Sydow 1948; Honko 1962, 1964), might have an empirical reality; and the notion of memorate informed by Honko's model could fruitfully be applied to certain kinds of medieval texts (Lindow 1986, 2011). The more experience-centered approach of David Hufford would offer a different kind of approach to cultural competence in this area (Hufford 1982). ${ }^{10}$

While these aspects of cultural competence fall into what often has been called "folk belief," folklore scholarship should warn us against such a unified hegemonic notion. Not only is the term "belief" itself fraught, but "belief," or perhaps better human conceptual frameworks, are constantly being renegotiated and adjusted through the meaningful interaction among individual and collective

8 A few Old English charms do make reference to mythic figures but do not recount narratives.

9 The poem Volundarkviða (Lay of Volundr) recounts a story about the Nordic analogue to Wayland the smith, elsewhere a figure of heroic legend. This poem contains no gods but is set before the end of the mythological section of the manuscript. Scholars believe that is was put there because Volundr may be referred to as a prince of the álfar; the word is cognate with elves but refers to beings regarded as deities in the mythology.

10 The excellent study of erotic supernatural beings and demonic sexuality by the Swedish historian Mikael Häll (Häll 2013) draws on material from both historical and folklore archives to show how the authorities in early modern Sweden tried to come to grips with apparently empirical sexual encounters between human and Other beings. 
members of social groups, through what broadly speaking falls under the rubric of "performance." It really will not do to say something like "People believed in the efficacy of prayer to saints" or "People believed in the existence of elves." We need to know first what "believed" means in these statements and second how and why and under what circumstances people activated certain conceptual frameworks.

Oral transmission and performance does not guarantee the presence of folklore, just as folklore does not require oral transmission, as the internet and the proliferation of memes in a multitude of forms in contemporary culture show clearly. But as I mentioned above, most people during the Middle Ages lived in an essentially oral culture, much if not most of which is lost to us now. To get an idea of the extent of an oral tradition, of the stability and variation that are possible, we may turn, for example, to the hundreds of thousands of items in the archives of the Finnish Literary Society in Helsinki, the repository of the prodigious collecting mentioned above. Even a cursory examination of this material shows that there almost countless numbers of poems in the narrative tradition (remember, even this may just be the tip of the iceberg), but that there are numerous semantic centers within the narratives reflecting both past modes of thought (Siikala 2002) and present (Tarkka 2013). We should bear this in mind when thinking about any more or less unique work that may reflect oral tradition, such as Beowulf or the Chanson de Roland.

Moving beyond an older view about the requirement that oral transmission of, say, narratives not be tainted with written texts, folklorists have come to understand how complicated the issue is. Far from being a situation of either-or, the issue of how people acquire their cultural competence in a mixed oral and literary culture must be regarded as both-and. Just as written texts can inform cultural competence of oral performance, so "oral practices" can inform the cultural competence of the scribal world (O'Keefe 1999, 2012; Quinn 2000). This hybridization comes particularly to the fore in the issue of textualization, of getting from oral performance(s) to written texts (Honko 2000). Folklore has grappled with this problem essentially from the beginning of the discipline, as both the Grimms' continuing tinkering with their tales (Schmidt 1932) and analysis of the language (Robinson 2010) clearly show. However, to some degree it had solved some of the problems, at least theoretically, when the field was still nascent. When Svend Grundtvig set out to edit the Danish ballads he stated his intention to present all the recordings of each ballad to which he had access, entire and complete. This was a wholly new way to think about the publication of ballads, which had been in print in Denmark since the sixteenth century (Vedel 1591), and which had always been presented as a single text, often composite, of each ballad. Adherents of this usual way reacted vociferously to Grundtvig's plan, and the conflict played out in the public eye (Petersen 1905) in the early 1850s. After the exchange of several polemics, Grundtvig had his way, and Danmarks gamle folkeviser does indeed print all the known versions, written and oral, for all the Danish ballads, along with information on provenance, singers, and so forth. In other words, no single version was privileged. This was completely contrary to the textual criticism of the time, and it may bear a lesson for today. Most medieval texts have been edited classically, either constructing a theoretical original text on the basis of the manuscript variants (sometimes with a variorum apparatus) or using a "best text" as the basis of an edition. This process of textualization has led to all sorts of issues; in Old Norse scholarly circles, for example, a running joke is "Einar Ólafur Sveinsson was the author of Njáls saga," since most of us know the text, a product of the thirteenth century that is extant in numerous quite variant manuscripts, from his edition (Einar Ól. Sveinsson 1954), which is very short on variant apparatus. ${ }^{11}$ The greatest poem of the Icelandic Middle Ages, Voluspá (Seeress's prophecy), is extant in two manuscripts along with citations of some stanzas in several manuscripts of the work of the mythographer Snorri Sturluson. In the nineteenth century Sophus Bugge edited the versions separately in his edition of the Poetic Edda (Bugge 1867), but that was contrary to usual practice, and the edition that was standard until quite

11 See (Quinn 2016) for an excellent treatment of these issues. 
recently has a composite text. A folklorist would look at the variant texts as different "performances" and would talk not about Voluspá but rather about the versions. Such good sense was recognized by the editors of the new edition (one of whom, Vésteinn Ólason, is also a ballad scholar), in which the versions are edited separately (Jónas Kristjánsson and Vésteinn Ólason 2014, pp. 292-321; see also Quinn 2000). Grundtvig's edition thus to some degree anticipated the performance turn in folklore studies, and the editors of the new edition have, one might say, met the challenge it posed.

It may seem self-evident that "images on the edge" (Camille 1992) stand in relation to adjacent text or objects as popular culture does to institutional culture, and there is certainly a case for treating manuscript marginalia, gargoyles, misericords, and the like, as more like folklore than the manuscripts and buildings that contain them. And yet, perhaps paradoxically, the use of the internet as a medium for the performance of folklore may be helpful in thinking about centers and margins. Internet providers offer a channel, and individual expression takes place that is not necessarily what the providers envision but that is within the parameters set by the providers, in a kind of institutional/vernacular hybridity (Howard 2015). Such institutional/vernacular hybridity appears to be particularly important in creating the circumstances under which certain kinds of materials were encoded. But beyond that, it may be illuminating to think of such hybridity closer to the center, not just as the mode that allowed production of the marginal. The first books in Iceland were in Latin, but around 1120 the priest Ari Porgilsson wrote a brief history of Iceland with treatment of its settlement, conversion to Christianity, and ecclesiastical development. Ari's Íslendingabók (book of Icelanders) was the first vernacular work in Iceland and clearly written from within the power center. But given its break with the use of Latin and break with the kinds of things that were being written down at the time, perhaps we should think of it as an expression of the hybridity of institution and communication.

I began these remarks by highlighting the early relationship between the fields of folklore and medieval studies and. Although folklore in effect grew out of medieval studies, it later grew in new and exciting directions, some of which have profited medieval studies and might continue to do so.

Conflicts of Interest: The author declares no conflict of interest.

\section{References}

Bellah, Robert N. 2011. Religion in Human Evolution: From the Paleolithic to the Axial Age. Cambridge and London: The Belknap Press of Harvard University Press.

Bugge, Sophus. 1867. Norrœn Fornkvæði: Islandsk Samling af Folkelige Oldtidsdigte om Nordens Guder og Heroer: Almindelig Kaldet Sxmundar Edda. Christiana: Malling.

Camille, Michael. 1992. Image on the Edge: The Margins of Medieval Art. Cambridge: Harvard University Press.

Einar Ól. Sveinsson, ed. 1954. Brennu-Njáls saga. Íslenzk fornrit, 12; Reykjavík: Hið íslenzka fornritafélag.

Frake, Charles O. 1964. How to Ask for a Drink in Subanun. American Anthropologist 66: 127-32. [CrossRef]

Grimm, Jacob, and Wilhelm Grimm. 1812. Das Lied vom Hildebrand und Hadubrand und das Weissenbrunner Gebet: Zum Erstenaml in Ihrem Metrum Dargestellt und Herausgegeben. Cassell: Thurneisen.

Grimm, Jacob, and Wilhelm Grimm. 1812-1815. Kinder- und Hausmärchen. Berlin: Verl. der Realschulbuchh.

Grimm, Jacob, and Wilhelm Grimm. 1815a. Der Arme Heinrich von Hartmann von der Aue. Berlin: Verl. der Realschulbuchh.

Grimm, Jacob, and Wilhelm Grimm. 1815b. Die Lieder der Alten Edda. Berlin: Verl. der Realschulbuchh.

Grimm, Jacob, and Wilhelm Grimm. 1816-1818. Deutsche Sagen. Berlin: in der Nicolaischen Buchhandlung.

Hafstein, Valdimar Tr. 2001. Biological Metaphors in Folklore Scholarship: An Essay in the History of Ideas. Arv: Nordic Yearbook of Folklore 57: 7-32.

Häll, Mikael. 2013. Skogsrået, Näcken och Djävulen: Erotiska Naturväsen och Demonisk Sexualitat i 1600- och 1700-talet. Stockholm: Malört.

Honko, Lauri. 1962. Geisterglaube in Ingermanland. FF Communications, 185; Helsinki: Suomalainen Tiedeakatemia. Honko, Lauri. 1964. Memorates and the Study of Folk Belief. Journal of the Folklore Institute 1: 5-19. [CrossRef] Honko, Lauri, ed. 2000. Textualization of Oral Epics. Trends in Linguistics, Studies and Monographs, 128; The Hague: Mouton. Howard, Robert Glenn. 2015. Why Digital Network Hybridity is the New Normal (Hey! Check This Stuff Out). Journal of American Folklore 128: 247-59. [CrossRef] 
Hufford, David J. 1982. The Terror that Comes in the Night: An Experience-Centered Study of Supernatural Assault Traditions. Philadelphia: University of Pennsylvania Press.

Hultkrantz, Åke. 1960. General Ethnological Concepts. In International Dictionary of Regional European Ethnology and Folklore. Copenhagen: Rosenkilde and Bagger, vol. 1, p. 94.

Jolly, Karen Louise. 1996. Popular Religion in Late Saxon England: Elf-Charms in Context. Chapel Hill: Univeristy of North Carolina Press.

Jónas Kristjánsson, and Vésteinn Ólason, eds. 2014. Eddukvæði: I: Goðakvædi. Íslenzk Fornrit. Reykajvík: Hið Íslenzka Fornritafélag.

Kapaló, James Alexander, ed. 2013. The Power of Words: Studies on Charms and Charming in Europe. Budapest and New York: Central European University Press.

Krohn, Kaarle. 1891. Mann und Fuchs: Drei Vergleichende Märchenstudien. Helsingfors: J. C. Frenckell.

Krohn, Kaarle. 1926. Die Folkloristische Arbeitsmethode, Begründet von Julius Krohne und Weitergeführt von Nordischen Forschern. Instituttet for Sammenlignende Kulturforskning, Serie B, 5; Oslo, Leipzig, Paris, London and Cambridge: Aschendorff.

Krohn, Kaarle. 1971. Folklore Methodology: Formulated by Julius Krohn and Expanded by Nordic Researchers. Translated by Roger Welch. Publications of the American Folklore Society, Bibliographical and Special Series, 21; Austin and London: The University of Texas Press for the American Folklore Society.

Lindahl, Carl. 1987. Earnest Games: Folkloric Categories in the Canterbury Tales. Bloomington and Indianapolis: Indiana University Press.

Lindow, John. 1986. Porsteins páttr skelks and the Verisimilitude of Supernatural Experience in Saga Literature. In Structure and Meaning in Old Norse Literature: New Approaches to Textual Analysis and Literary Criticism. Edited by John Lindow, Lars Lönnroth and Gerd Wolfgang Weber. Viking Series, 3; Odense: Odense University Press, pp. 264-80.

Lindow, John. 2006. Narrative Worlds, Human Environments, and Poets: The Case of Bragi. In Old Norse Religion in Long-Term Perspectives: Origins, Changes, and Interactions. Edited by Anders Andrén, Kristina Jennbert and Catharina Raudvere. Vägar till Midgård, 8; Lund: Nordic Academic Press, pp. 21-25.

Lindow, John. 2011. Meeting the Other: The Cases of Draumr Porsteins Síðu-Hallssonar and Kumlbúa páttr. In Myths, Legends and Heroes: Studies in Old Norse and Old English Literature in Honour of John McKinnell. Edited by Daniel Anlezark. Toronto: University of Toronto Press, pp. 77-90.

Lindow, John, and Jens Peter Schjødt. Forthcoming. The Divine, the Human, and In-Between. In Pre-Christian Religions of the North. Edited by Jens Peter Schjødt, John Lindow and Anders Andrén. Turnhout: Brepols, vol. 2.

Mandel, Jerome, and Bruce A. Rosenberg, eds. 1970. Medieval Literature and Folklore Studies: Essays in Honor of Francis Lee Utley. New Brunswick: Rutgers University Press.

Mitchell, Stephen A. 2011. Witchcraft and Magic in the Nordic Middle Ages. Philadelphia and Oxford: University of Pennsylvania Press.

O'Keefe, Katherine O'Brien. 1999. Visible Song: Transitional Literacy in Old English Verse. Cambridge Studies in Old English, 4; Cambridge: Cambridge University Press.

O'Keefe, Katherine O'Brien. 2012. Orality and Literacy. In Oral Literature of the Middle Ages. Edited by Karl Reichl. Berlin: Walter de Gruyter, pp. 120-39.

Olrik, Axel. 1908. Episke love i folkedigtningen. Danske Studier 5: 69-89.

Olrik, Axel. 1909. Epische Gesteze der Volksdichtung. Zeitschrift für Deutsches Altertum 1: 1-12.

Olrik, Axel. 1965. Epic Laws of Folk Narrative. In The Study of Folklore. Edited by Alan Dundes. Translated by Jean Steager. Englewood Cliffs: Prentice-Hall, pp. 129-41.

Pentikäinen, Juha. 1971. Julius and Kaarle Krohn. In Leading Folklorists of the North. Edited by Dag Strömbäck. Oslo: Universitetsforlaget, pp. 11-33.

Petersen, Carl S. 1905. Fra folkevisestriden. Danske Studier 2: 65-114.

Piø, Iørn. 1971. Svend Grundtvig. In Leading Folklorists of the North. Edited by Dag Strömbäck. Oslo: Universitetsforlaget, pp. 189-224.

Quinn, Judy. 2000. From Orality to Literacy in Medieval Iceland. In Old Icelandic Literature and Society. Edited by Margaret Clunies Ross. Cambridge: Cambridge University Press, pp. 30-60. 
Quinn, Judy. 2016. The Principles of Textual Criticism and the Interpretation of Old Norse Texts Derived from Oral Tradition. In Studies in the Transmission and Reception of Old Norse Literature: The Hyperborean Muse. Acta Scandinavica 6; Turnhout: Brepols, pp. 47-78.

Robinson, Orrin W. 2010. Grimm Language: Grammar, Gender and Genuineness in the Fairy Tales. Linguistic Appraoches to Literature, 10; Amsterdam: Benjamins.

Schmidt, Karl. 1932. Die Entwicklung der Grimmschen Kinder-und Hausmärchen Seit der Urhandschrift Nebst Einem Kritischen Texte der in die Drucke Übergegangenen Stücke. Hermaea, 30; Halle (Saale): M. Niemeyer.

Siikala, Anna-Leena. 2002. Mythic Images and Shamanism: A Perspective on Kalevala Poetry. FF Communications, 280; Helsinki: Suomalainen Tiedeakatemia.

Tarkka, Lotte. 2013. Songs of the Border People: Genre, Reflexivity, and Performance in Karelian Oral Poetry. FF Communications, 305; Helsinki: Suomalainen Tiedeakatemia.

Taylor, Archer. 1927. The Black Ox: A Study in the History of a Tale. FF Communications, 70; Helsinki: Suomalainen tiedeakatemia.

Taylor, Archer. 1970. The Anecdote: A Neglected Genre. In Mandel and Rosenberg. New Brunswick: Rutgers University Press, pp. 223-28.

Thompson, Stith. 1970. Unfinished Business: The Folktale. In Mandel and Rosenberg. New Brunswick: Rutgers University Press, pp. 213-21.

Vedel, Anders Sørensen. 1591. Et Hundrede Udvaalde Danske Viser om Allehaande Merkelige Krigsbedrifft ... Konger, Kjæmper, og Andre. Ribe: Hans Brun.

Von Sydow, Carl Wilhelm. 1948. Kategorien der Prosa-Volksdichtung. In Selected Papers on Folklore: Published on the Occasion of his Seventieth Birthday. Copenhagen: Rosenkilde and Bagger, pp. 60-88.

Wilson, William A. 1973. Herder Folklore and Romantic Nationalism. Journal of Popular Culture 6: 819-35. [CrossRef]

(C) 2018 by the author. Licensee MDPI, Basel, Switzerland. This article is an open access article distributed under the terms and conditions of the Creative Commons Attribution (CC BY) license (http:/ / creativecommons.org/licenses/by/4.0/). 